Finance and Economics Discussion Series Divisions of Research \& Statistics and Monetary Affairs Federal Reserve Board, Washington, D.C.

\title{
Convenience or Necessity? Understanding the Recent Rise in Credit Card Debt
}

\section{Kathleen W. Johnson}

2004-47

NOTE: Staff working papers in the Finance and Economics Discussion Series (FEDS) are preliminary materials circulated to stimulate discussion and critical comment. The analysis and conclusions set forth are those of the authors and do not indicate concurrence by other members of the research staff or the Board of Governors. References in publications to the Finance and Economics Discussion Series (other than acknowledgement) should be cleared with the author(s) to protect the tentative character of these papers. 


\title{
CONVENIENCE OR NECESSITY? UNDERSTANDING THE RECENT RISE IN CREDIT CARD DEBT
}

\author{
Kathleen W. Johnson, Economist \\ Division of Research and Statistics \\ Board of Governors of the Federal Reserve System
}

\begin{abstract}
Economists disagree whether the recent increase in credit card debt has been detrimental to U.S. households. 'However, many rely on a measure of revolving credit published by the Federal Reserve, which captures transactions in which a credit card is used because of its advantages over cash or a check. An increase in debt stemming from such convenience use likely would not signal greater financial vulnerability for households. In this paper, I present evidence that some of the significant increase in both the level of credit card debt and its growth from 1992 to 2001 was due to convenience use.
\end{abstract}

\footnotetext{
${ }^{1}$ I thank Stephanie Aaronson, Karen Dynan, Erik Heitfield, Leslie Hull, Karen Pence, Nick Souleles, Victor Stango and participants in seminars sponsored by the Board of Governors of the Federal Reserve System, the Western Economic Association (July 2002), the American Economic Association (January 2003), the University of Maryland, and Federal Reserve System Applied Microeconomics Conference (June 2004) for valuable feedback on an earlier version of this paper. I also thank Doris Sum for research assistance and Christopher Karlsten for editing assistance. The views presented here are solely those of the author and do not necessarily reflect the views of the Board of Governors or members of its staff. Comments may be sent to Kathleen.W.Johnson@frb.gov.
} 
The growth of credit card debt has been brisk over the past decade. Between 1993 and 2003, revolving consumer credit, most of which consists of credit card debt, grew at an annual rate of 9.2 percent, whereas disposable personal income grew only 5.2 percent. As a result, the ratio of revolving credit to income increased 2.7 percentage points, to 8.9 percent.

Despite their agreement about the growth of credit card debt, many analysts differ on the question of whether this growth is detrimental to the U.S. consumer. Academic researchers have consistently found that rapid credit growth signals rapid future consumption growth (see e.g., Maki, 2000; Ludvigson, 1999; Bacchetta and Gerlach, 1997; Carroll and Dunn, 1997). ${ }^{2}$ Others, however, have often interpreted the growth in credit in a negative light. Among recent examples, an Associated Press article published earlier this year suggested that the doubling of consumer debt in the past decade is now causing financial difficulties for the U.S. household (Powell, 2004). Taking a longer view, a study of news articles about consumer credit found that $65-80$ percent of such articles published in the New York Times in the last half-century had at least a somewhat negative tone (Durkin and Jonasson, 2002).

Whatever their views on the effect of credit card debt, many analysts rely on an aggregate measure of revolving credit published by the Federal Reserve. Some observers may misinterpret this measure over long periods because it captures the "convenience use" of credit cards. That is, the measure includes transactions in which a credit card is used as a medium of exchange because it provides advantages not offered by cash or a check. ${ }^{3}$ Because, by definition, households have the means to pay off convenience-use debt, an increase in aggregate household

\footnotetext{
${ }^{2}$ Researchers have often interpreted the positive, independent effect of credit on consumption as reflecting an increased willingness of financial institutions to make loans to households. An increase in the supply of credit may contribute to higher consumption because it increases a household's available liquid resources. For example, if a household wants to consume more than its current income--perhaps because it wishes to smooth through a temporary income shock--but cannot obtain enough credit to satisfy its wants, it may have to restrict its consumption; once lenders extend it more credit, it will consume more. Gross and Souleles (2002) provide further support for the positive correlation between credit and consumption by finding that in precautionary savings models of household consumption, even households that can easily obtain credit may boost consumption in response to an exogenous increase in credit supply.

${ }^{3}$ Whitesell (1992) suggests that "cards would dominate checks if they were associated with both lower holding costs and lower transactions costs."
} 
debt stemming from convenience use likely would not signal greater financial vulnerability for households.

In this paper, I estimate the effect of convenience use on the level of measured credit card debt from 1992 to 2001. In preparing my estimate, I calculate the growth of convenience use and its share of measured credit card debt over that period. Aggregate data on convenience use are available but are insufficient for this purpose in that they cannot separate the growth of convenience use from new charges that the household intends to revolve beyond the current billing cycle, which I will refer to new borrowing. Therefore, I use household-level data on credit card charges to isolate convenience use from new borrowing, constructing a Tobit model of the credit card charges of households surveyed in the 1992, 1995, 1998, and 2001 waves of the Survey of Consumer Finances (SCF). I conclude that convenience use likely had a significant impact on the level and growth of credit card debt from 1992 to 2001.

\section{History of Convenience Use}

The use of credit cards for convenience helped to create and expand the credit card market. Credit cards were initially invented to satisfy consumers' demand for a convenient payment method rather than to satisfy the demand for credit. The earliest payment cards were more useful for convenience than for new borrowing because they were charge cards whose balances had to be paid in full each month. In 1950, Diners Club established the first payment card in the United States - a charge card that could be used in several Manhattan restaurants. The first credit cards were issued eight years later.

The convenience use of credit cards grew, and cards began to replace cash and checks as a means of payment in more and more transactions. The reasons for this development were more complicated than the term "convenience use" might imply. Credit cards were not just more convenient than cash and checks; they also provided the consumer with several advantages that cash and checks could not provide. Three such advantages are the following: First, credit cards permit households to earn interest on their funds during the period between the transaction and the payment of the credit card bill. Second, credit card payments are more secure than cash payments. Third, merchants can often process credit card transactions faster than check transactions, saving time for the household. 
The demand for credit cards as a substitute for cash and checks has been studied in the literature on the transactions demand for money (see e.g., Duca and Whitesell, 1995; White, 1976; Mandell, 1972). Researchers have found that households with credit cards tend to have lower balances in their transactions accounts than do households without credit cards. ${ }^{4}$ Three reasons for the lower balances are that (1) credit cards can replace emergency funds (precautionary balances), (2) households can hold the funds needed to pay off their credit cards in higher-yielding assets, and (3) households can time the payment of their card debt with the receipt of their income so that the funds used to pay off card balances spend little time in transactions accounts. These findings provide indirect evidence that the level of convenience use is significant because they require that the dollar amount of this transactions use (or convenience use) is large relative to household transaction accounts.

From the late 1980s through the 1990s, convenience use grew as financial institutions responded to increasingly intense competition by offering rewards for heavy credit card use; that trend has continued into the 2000s. For example, many general-purpose cards offer cash-back rebates on purchases, and some of these rebates are as high as 5 percent. Store cards also reward convenience use by offering discounts on merchandise. These programs encourage convenience use because they generally do not require the cardholder to revolve the balance to receive the discount; such a requirement would reduce the program's benefits for convenience users. ${ }^{5}$

Convenience use has also grown because opportunities for convenience-use transactions have risen considerably in the past decade. ${ }^{6}$ Shopping over the Internet and through the mail has increased quite a bit, boosting the demand for credit cards as a payment device. Electronic

\footnotetext{
${ }^{4}$ Transactions accounts are checking, savings, and money market accounts as well as cash accounts at brokerages.

${ }^{5}$ Card issuers can benefit an increase in convenience use transactions because they receive revenue from the merchant fees levied on each transaction.

${ }^{6}$ However, the increase in these opportunities has also enabled the growth of a substitute for the convenience use of credit cards - the use of debit cards. Zinman (2004) and Klee (2004) document the growth of debit card use. Zinman provides evidence that the consumer's choice between credit and debit can be explained by standard theory, in particular households who cannot take advantage of float because they revolve their credit card balances tend to use debit cards. Klee documents the household characteristics that determine this choice of payment. Changes in the salient parameters of this choice may have led to an increase in debit card use, perhaps at the expense of convenience use.
} 
commerce has increased 26 percent per year since 1999, the first year in which the Bureau of Economic Analysis collected data on e-commerce sales. ${ }^{7}$ Even traditional brick-and-mortar stores have increased their acceptance of credit cards. In 1989, about 2-3/4 million merchants accepted VISA cards; by 2000, that number had reached 4-1/4 million. ${ }^{8}$

\section{Effect of Convenience Use on Measured Credit Card Debt}

Convenience use clearly raises the measured level of credit card debt outstanding because the data on this debt are collected from financial institutions as of the end of each month without regard to when the debt will be repaid. For example, if a consumer charges $\$ 500$ on the 15 th of one month and pays it off on the 15th of the next month, the data will capture the $\$ 500$ at the end of the month in which the charge was made. Thus, measured credit will include both debt that will be paid off in the next month (convenience use) and debt that will be paid off beyond the thirty-day horizon (amount borrowed). In addition, if convenience use constitutes a large fraction of measured credit card debt and rises more rapidly than the amount borrowed then measured credit will also grow faster than the amount borrowed.

\section{Evidence of Convenience Use from Aggregate Data}

As discussed earlier, convenience use helped create and expand the credit card market, but has it continued to play a large role in the growth of that market? Does convenience use account for an important share of measured credit card debt? For answers to these questions, I first consult two aggregate measures of convenience use. One aggregate measure, calculated by the Federal Reserve from bank data, suggests that convenience use currently equals about 10 percent of measured credit card debt and that it has grown at about the same rate as the amount borrowed. However, the other aggregate measure, a ratio of credit card transactions to credit card debt, suggests that convenience use has grown considerably faster than the amount borrowed.

\footnotetext{
${ }^{7}$ The Census Bureau defines e-commerce sales as "sales of goods and services where an order is placed by the buyer or price and terms of sale are negotiated over an Internet, extranet, Electronic Data Exchange (EDE) network, electronic mail, or other online system.”

${ }^{8}$ However, not all merchants have encouraged convenience use, perhaps because of the merchant fee associated with credit cards. Anecdotally, some merchants have offered discounts for consumers who choose to pay with cash rather than with a credit card.
} 
Both aggregate measures suffer from the same deficiency--namely, they fail to separate the growth of convenience use from that of new borrowing.

\section{Federal Reserve Survey}

A measure of convenience use can be calculated from the Federal Reserve's survey of twenty-

four card-issuing banks. ${ }^{9}$ Survey respondents report the total ending balance for all accounts and the total ending balance for all accounts with finance charges. The difference between these two balances measures convenience use, which generally does not carry finance charges. As a share of the total ending balance on all credit card accounts, this measure has been fairly steady at about 10 percent since it first became available in 1994, an indication that convenience use and the amount borrowed have grown at about the same rate.

This measure is only a rough proxy for convenience use and may overstate its actual level. Reasons other than convenience use may account for a lack of finance charges. For example, some of the balances on accounts without finance charges may be new borrowing that will be revolved in the future, particularly if the account is new. And the number of new accounts increased significantly in the 1990s: According to VISA, the number of accounts per U.S. citizen rose from 0.5 in 1990 to 0.9 in 2000 .

\section{Ratio of Credit Card Transactions to Credit Card Debt}

A second commonly used measure of convenience use indicates, in contrast to the Federal Reserve data, that convenience use grew rapidly from 1992 to 2001. This measure, the ratio of the dollar volume of credit card transactions to outstanding credit card debt, remained essentially flat between 1992 and 1995 and then increased steadily, from a little less than 2.0 in 1992 to more than 2.8 in 2001 (chart 1).

As with the data from the Federal Reserve survey, the rise in this measure may reflect not only convenience use, but also the amount of new borrowing. If the growth of new borrowing rises from one period to the next, the ratio of transactions to outstanding debt will also rise.

\footnotetext{
${ }^{9}$ As of December 2003, these banks held or securitized 60 percent of the credit card loans in the banking industry.
} 


\section{Evidence of Convenience Use from Household-Level Data}

Unlike the aggregate data just examined, household-level data on credit card charges permit the isolation of convenience use from new borrowing. These data indicate that convenience use may be closer to 7 percent of measured revolving consumer credit or may be as low as 5 percent.

Data from the SCF, which asks households about their credit card payment behavior, suggest that a large share of households always or almost always pay off their cards each month and that the credit card charges of these households represent a sizable portion of measured credit card debt. However, these so-called convenience users also use their cards to increase their amount borrowed, and so these charges should not be considered entirely convenience use. The rest of the paper uses econometric techniques to separate convenience use from new borrowing.

\section{Simple Estimate of Convenience Use}

One estimate of convenience use is simply the amount of credit card charges by households that always or almost always pay off their credit cards. That the proportion of convenience users has risen only slightly from 1992 to 2001 suggests that much of the new growth in convenience use represented mainly higher convenience use by current convenience users. Since 1992, 51-55 percent of households reported that they always or almost always paid off the total balance owed on their credit card accounts each month (table 1). ${ }^{10}$ Another 19-20 percent of households sometimes paid off their balance, and the remaining households hardly ever did; I refer to the last two groups as revolvers.

The typical convenience user charges more than the typical revolver, a finding that is consistent with the idea that convenience use generates credit card charges beyond the demand for new borrowing (chart 2). From 1992 to 2001, the median monthly charge of convenience users was as much as \$216 higher than that of revolvers. In addition, during this period convenience users increased their charges more than revolvers. The median monthly charge of convenience users increased about \$130, from \$233 in 1992 to \$363 in 2001, whereas the average charge of revolvers increased only \$30, from \$117 in 1992 to \$147 in 2001.

Relying on these simple statistics, one may conclude that convenience use represents a fairly sizable share of measured credit card debt outstanding. Total measured debt in the SCF

\footnotetext{
${ }^{10}$ All results in this paper based on the Survey of Consumer Finances are weighted using population weights.
} 
equals the amount borrowed on credit cards plus convenience use, which may be proxied by the charges of convenience users. According to these calculations, convenience use represents 15-20 percent of measured credit card debt (table 2).

Although these statistics suggest that convenience use makes up a sizable portion of measured credit card debt and that it has increased more rapidly than the amount borrowed, they do not account for new borrowing by convenience users. Nearly one-fourth of convenience users have positive balances on their credit cards, and the average balance for these households is about $\$ 1,700$. Some of the charges of convenience users may include the demand for new borrowing, a possibility that I address in my regression model of a household's credit card charges (see discussion below).

Another consideration when interpreting these statistics is that convenience users may have altered their borrowing behavior from 1992 to 2001 because of changes in their household characteristics. Several characteristics that plausibly affect the demand for credit card debt changed over this period. The percentage of cardholders in 1992 who had unusually low income in the previous year exceeded that of cardholders in the same category in 2001, and the percentage of cardholders who were unemployed was higher in 1992 than in 2001. Cardholders were wealthier in 2001 than in 1992; average net worth increased more than $\$ 200,000$. At the same time, the percentage of cardholders who were married was lower in 2001 than in 1992. Finally, cardholders in 2001 were significantly less myopic than those in 1992 in the sense that the share of households with a financial planning period of greater than one year rose 7 percentage points between 1992 and 2001.

The growth of convenience use may be influenced by changes in cardholder characteristics. For example, suppose that myopic cardholders tend to charge more on their credit cards than forward-looking cardholders because they do not recognize the high long-run cost of credit card borrowing. If convenience users become less myopic relative to other households, then they will increase their charges more slowly than other households, and the importance of growth in convenience use will be understated.

\section{Tobit Estimate of Convenience Use}

Because the simple measure of convenience use - the charges of convenience usersmay include new borrowing, I estimate a model that separates convenience use from the demand 
for new borrowing. This model is based on a standard consumption model that accounts for convenience use, which is measured by a dummy variable for convenience users. I specify a Tobit model because the dependent variable - the demand for charges - is censored at zero. According to the Tobit estimates, convenience use makes up about one-half of the credit card charges of convenience users and accounts for about 7-1/2 percent of measured credit card debt. This estimate is fairly robust to several different specifications; the range of estimates for these specifications is about 5-10 percent, with an average share close to the baseline estimate.

To estimate convenience use while accounting for the demand for new borrowing by both convenience users and other types of credit card users, I specify a model of the demand for credit card charges and estimate the effect on this demand of household characteristics, including whether a household uses its card mainly for convenience. I propose a model of household demand for credit card charges that is composed of two parts: the household's desire to change its level of credit card debt (demand for new borrowing) and its demand for convenience.

A household's demand for new borrowing is derived from its demand for consumption. A fully rational, forward-looking household chooses its desired consumption for each period of its lifetime by maximizing its lifetime utility, subject to the constraints of its lifetime budget. This consumption plan specifies the household's desired consumption in each period given its expected lifetime income, its current wealth, demographic considerations (such as whether children are present in the household), the interest rate, and the household's preference for utility today relative to sometime in the future.

Consumption $=f($ income, wealth, demographics, interest rate, rate of time preference $)$

Debt (and its converse, assets) allows a household to follow a desired consumption plan that is somewhat independent of its income path; a household can use debt to "front-load" consumption if its current income is low relative to its expected future level and to smooth consumption through fluctuations in income. In many models of consumption, households dislike large fluctuations in consumption and plan instead on a smooth consumption path. For example, in a model with uncertain future income and risk-averse households, such households generally plan to consume less than 100 percent of their fluctuations in income, an indication that they intend to smooth their consumption over time (Deaton, 1992). ${ }^{11}$ A household may save

${ }^{11}$ The degree of consumption smoothing depends on two factors: (1) a household's level of certain assets relative to its level of uncertain assets and (2) the process that describes its income 
some of its current income to smooth through fluctuations in its realized income, but a young or an impatient household may not have sufficient precautionary savings to smooth consumption as much as it desires and thus may have to use debt instead.

A household's new borrowing equals the difference between its desired consumption and its current resources - defined as current income plus the change in non-credit-card wealth. New borrowing = consumption $-($ income + change in other wealth $)$

And the demand for credit card charges is equal to consumption demand minus current resources plus convenience use.

Credit card charges $=$ consumption $-($ income + change in other wealth $)+$ convenience use

I specify an econometric model by assuming that a household's optimal consumption function is linear in its parameters, $\beta$, and by denoting the demand for new borrowing of household h by $x_{h} \beta$, where $x_{h}=\left(\right.$ income $_{h}$, wealth $_{h}$, demographics $_{h}$, interest rate ${ }_{h}$, time preference $\left._{h}\right)$

I denote the convenience demand of household $h$ as $c_{h}$, a dummy for whether the household always or almost always pays off its credit card. I interact $c_{h}$ with time dummies to test whether convenience demand has changed over time. Finally, I assume that the demand for charges is observed with some normally distributed error. Given these assumptions, I estimate the following model:

Credit card charges $s_{h, t}=x_{h} \beta+\gamma_{1} c_{h}+\gamma_{2, t} c_{h} t+\varepsilon_{h, t}$

The expression $x_{h} \beta$ captures credit card charges that change a household's level of borrowing, whereas $\gamma_{1} c_{h}+\gamma_{2, t} c_{h} t$ captures charges made for convenience; thus, credit card charges can be separated into new borrowing and convenience use. ${ }^{12}$

The OLS estimator likely understates the true parameters of this model of convenience use because the dependent variable — charges — is left-censored. Although the demand for

path. In some models with plausible income processes, households consume more than 100 percent of income changes, rendering consumption more volatile than income.

${ }^{12}$ One weakness of this approach is that convenience use is defined as the "extra" charges made by households that typically pay off their credit cards "always or almost always." In assuming that revolvers do not often use their cards for convenience, this approach may underestimate the amount of convenience use. 
charges may be positive or negative (it is negative for a household that does not charge for convenience and that repays its credit card debt), the minimum charge recorded is zero. The proportion of households whose charges are censored has the potential to be large, implying that the OLS estimates probably significantly understate the true parameters. ${ }^{13}$ In the 1992-2001 waves of the SCF, 13 percent of card-holding households reported no charges; which suggests that the OLS parameter estimates are approximately $7-1 / 4$ percent too small. ${ }^{14}$ A Tobit estimator can account for censoring in the demand for charges and should more closely approximate the true change in convenience use.

Credit card charges ch,t $=\max \left(0, x_{h} \beta+\gamma_{I} c_{h}+\gamma_{2, t} c_{h} t+\varepsilon_{h, t}\right)$

The results from the Tobit estimation are presented in Table 3. As shown, convenience use significantly raised credit card charges. In 1992, the marginal effect of convenience use after controlling for other household characteristics was $\$ 182$, which equaled about 43 percent of the average credit card charge in that year. Second, the effect of convenience use increased over time. Because the marginal effect of convenience use in 1995 is not significantly different from zero, convenience use also raised charges $\$ 182$ in that year, but by 1998 it had raised charges $\$ 368$, and by 2001 it had raised them $\$ 484 .^{15}$ I use the Tobit parameters to calculate convenience use, the aggregate amount of charges associated with being a convenience user. Convenience use $_{t}=\sum_{h}$ weight $_{h, t}\left(\hat{\gamma}_{1} c_{h}+\hat{\gamma}_{2, t} c_{h} t\right)$

where weight $_{h, t}$ is the population weight of household $h$ at time $t$. Convenience use made up about one-half of the charges of convenience users, but this share ranged from 28 percent in 1995 to 55 percent in 1992 (chart 3).

${ }^{13}$ The exact number of households whose new charges are censored is unknown because households that demand zero new charges cannot be separated from those whose demand is negative.

${ }^{14}$ Greene (1981, p. 505) shows that "the bias of the OLS estimator can be corrected by dividing each estimate by the sample proportion of nonlimit observations." This approximation requires that the dependent variable and the regressors be normally distributed, although Chung and Goldberger (1984) show that proportionality generally holds under less stringent assumptions.

15 The effect of convenience use in 1998 equals the coefficient on the 1992 dummy plus that on the 1998 dummy. The effect of convenience use in 2001 is calculated similarly. 
Because convenience use as calculated by the Tobit model accounts for significantly less than 100 percent of the total charges of convenience users, the estimate of convenience use as a share of measured credit card debt falls quite a bit relative to the simple estimate presented in the previous section. When the Tobit estimate of convenience use replaces this simple estimate, the share of convenience use falls from 15-21 percent of measured credit card debt to 4-11 percent (table 4). Moreover, the Tobit model estimates an average share of about $7 \frac{1}{2}$ percent across the years in the sample.

\section{Robustness of the Baseline Estimate of Convenience Use}

Because the Tobit, or baseline, results are somewhat sensitive to the specification of the model, I consider a range of estimates based on alternative specifications. However, even under these alternative specifications, convenience use as a share of measured credit card debt ranges between 5 percent and 10 percent.

The first alternative addresses the potential endogeneity of the convenience-user variable. The most likely source of endogeneity in this model is omitted variables that measure a household's attitude toward credit. For example, if a household believes that borrowing is bad in some sense, then it is likely to charge less than another household and to pay off its credit card more frequently. Because believing that borrowing is bad is positively correlated with being a convenience user but is negatively correlated with making credit card charges, the coefficient of the convenience-user dummy in the baseline specification may be biased downward.

A remedy for omitted-variable bias is to use proxies for the omitted influence. The 1995, 1998, and 2001 waves of the SCF offered good proxies for credit attitudes. Respondents to the SCF were asked whether they thought that buying things on the installment plan was generally a good idea or a bad idea. I added a dummy variable that takes a value of 1 for respondents who felt that buying on the installment plan was a bad idea. Respondents were also asked whether they approved of persons' borrowing money for various hypothesized purchases, such as a vacation trip or a car. I combined these questions into four dummy variables that equaled 1 if a household thought that incurring debt to buy the following items was a bad idea: luxury goods, general items when income declined, automobiles, and education. As expected, the coefficient on convenience use rose when the proxies for credit attitudes were included, increasing $6-1 / 2$ percent 
to $\$ 272 .{ }^{16}$ In addition, including the proxies raised the estimate of convenience use as a share of measured credit from an average of 7-1/2 percent over the 1995-2001 period to about 7-3/4 percent (chart 4).

The second alternative specification defines "credit card" more narrowly than does the baseline. Up to this point, the analysis has included charges on what are known as generalpurpose cards and store cards; the second alternative includes charges on general-purpose cards only. General purpose cards are affiliated with a card association such as Visa or MasterCard and are accepted at any location that honors cards from that association, whereas store cards are issued by a merchandiser and generally can be used to purchase items only from that merchandiser. Convenience use may vary between these two types of cards because of different restrictions on their use. For example, because general-purpose credit cards are accepted in more locations, they may be used for convenience more often than store cards.

The result of the alternative specification is consistent with the idea that households can use general-purpose cards for convenience in more places than they can use store cards: The share of convenience use is slightly higher for general-purpose cards than for general-purpose cards and store cards taken together. Convenience use for general-purpose cards as a share of total measured credit equals about 10 percent, which is similar to the share measured from aggregate bank data.

The SCF includes information on the interest rates of general-purpose cards, allowing me to include the interest rate in these regressions, which is the third alternative. The baseline regression omits this rate because it is not available for store cards or for any type of card in the 1992 SCF. I presume that the interest rate is negatively correlated with charges through the demand for credit; households paying higher interest rates demand less credit and charge less on their cards than do those with lower interest rates. If this omitted rate is correlated with convenience--that is, if convenience users are likely to have high interest rates - then the convenience-user dummy will become proxy for a high interest rate and bias the coefficient on convenience use downward. If convenience users are likely to have low interest rates, then the opposite bias will occur. According to the 1995-2001 waves of the SCF, households with higher

${ }^{16}$ Because the full set of credit-attitude variables are not included in the 1992 SCF, I compare the coefficient in this specification with the same coefficient from the baseline specification with the 1992 observations removed. 
interest rates charge less on their credit cards each month than do households with lower interest rates; the correlation between interest rates and charges is small—about - 0.01 — but not precisely estimated. However, a household's interest rate does not seem to be correlated with its being a convenience user; the correlation coefficient is only 0.003 . Therefore, the finding that the share of convenience use does not change when the interest rate is added to the regression is not surprising. Convenience use as a share of total measured credit falls 2 basis points - to 9.6 percent - when the interest rate is added to a regression model of the charges on general purpose cards in the 1995-2001 waves of the SCF.

The fourth alternative narrows the definition of a convenience user by removing households with outstanding balances. As mentioned earlier, nearly one-fourth of all convenience users have positive balances on their credit cards. Although they claim to pay off their credit cards "nearly always," they clearly revolve some portion of their charges; therefore, I reclassify them as revolvers rather than as convenience users.

Reclassifying them as revolvers reduces the share of convenience use in measured credit because the number of convenience users declines by one-fourth. When convenience users include only those who claim to pay off their cards regularly and in fact have no balances on their cards, convenience use amounts to only about $4-1 / 2$ percent of measured credit card debt rather than the $7-1 / 2$ percent in the baseline estimation.

The fifth alternative tests the result's sensitivity to outliers. Charges on credit cards vary widely from household to household in the sample, ranging from a minimum of $\$ 0$ to an eyepopping maximum of $\$ 158,000$. Credit card charges of this magnitude seem to be a fairly rare occurrence because such large purchases are often financed with other types of credit, such as a new car loan or a home equity loan. These large charges may represent convenience use that takes advantage of a credit card rewards program, but this atypical convenience use may be unduly influencing the results. In fact, although population weights are used in the regressions, removing households whose charges have a less than 1 percent chance of occurring reduces the share of convenience use to about 5-1/4 percent of measured credit.

The final alternative considers the possibility that the dependent variable may be rightcensored. In addition to being censored at zero, the demand for charges may be right-censored at the credit limit because households cannot costlessly borrow more than the lender is willing to loan them. Thus, even positive values of new household borrowing may not equal a household's 
desired new borrowing debt. I will not fully account for right-censoring because the number of censored observations is small and because testing the possibility of right-censoring would require modeling the supply of credit, which is beyond the scope of this paper. However, I did test to see if my results are sensitive to right-censoring.

By ignoring right-censoring, I risk a small downward bias in my estimates. About 3 percent of the households in the sample have outstanding credit card balances that are greater than 95 percent of their credit limits, and the vast majority of these households have outstanding balances equal to their credit limits. However, because a household's proximity to its credit limit

significantly affects its charges, the credit constraint may be binding. A household that is near its credit limit charges about $\$ 300$ less than does a similar household that has plenty of excess credit.

Although the credit limit significantly affects charges, it has a small effect on the convenience use estimate because households that pay off their cards regularly are generally not credit constrained. About 0.5 percent of convenience users are close to their credit limits, whereas about 5 percent of revolvers are. Removing from the regression households who are likely right-censored raises the estimate of convenience use as a share of measured credit to 7.9 percent.

In summary, alternative specifications of the model yield slightly different estimates of convenience use as a share of measured credit card debt. When the model is estimated for general-purpose cards only, the estimated share rises to almost 10 percent of measured credit card debt. On the other end of the range, redefining convenience users reduces the estimated share to $4-1 / 2$ percent. Other specifications vary within this range, and the baseline specification falls just below the average share of 7.7 percent. These alternative specifications suggest that convenience use accounts for about 5 to 10 percent of measured credit card debt on average over 1992 - 2001 They also indicate that convenience use may distort conclusions about household indebtedness that are based on measured credit card debt.

\section{Growth of Convenience Use}

Convenience use grew rapidly over my sample period, particularly when compared with the amount borrowed. Between 1992 and 2001, convenience use-as estimated in the previous 
section-grew $14 \frac{1}{2}$ percent per year on average, whereas the amount borrowed on credit cards grew only $6 \frac{1 / 2}{2}$ percent per year (chart 5$)$.

The growth of convenience use occurred mainly in the second half of the 1990s. This contour resembles that of a commonly cited aggregate measure of convenience use: the ratio of credit card transactions to outstanding credit card debt (see earlier discussion and chart 1). Had convenience use remained at its 1992 level, the growth of measured credit card debt would have been almost 1 percentage point per year slower between 1992 and 2001, and measured credit levels would have been $7-1 / 2$ percent lower (chart 6).

\section{Conclusion}

Convenience use notably boosted the growth of measured credit card debt from 1992 to 2001, with the convenience use share of this debt rising from about 6 percent in 1992 to 11 percent in 2001. Data from a Federal Reserve survey of banks suggest that convenience use accounted for about 10 percent of measured credit card debt, and transactions data from VISA imply that convenience use grew rapidly, but these findings may overstate convenience use because they also capture new borrowing. A Tobit model of charges that attempts to separate convenience use from new borrowing suggests that the proportion of convenience use was closer to $7 \frac{1}{2}$ percent and may have been as low as 5 percent.

Convenience use was also significant when compared with other economic aggregates. Using the baseline estimate of the share of convenience use in 2001, 10.8 percent, and the national aggregate measure of revolving credit in that year, $\$ 703.9$ billion, I calculate that convenience use in that year amounted to approximately $\$ 76$ billion dollars at a monthly rate, which was almost $\$ 1$ trillion at an annual rate. This level of convenience use amounted to about 13 percent of personal consumption expenditures or about 9 percent of gross domestic product.

The growth in this convenience use has been rapid, particularly in the latter part of the 1990s, possibly rising as much as 15 percent per year since 1992. Had convenience use remained at its real 1992 levels, rather than growing at this rapid pace, measured credit card debt would have grown a bit less than 1 percentage point slower per year since 1992, leaving its level 7-1/2 percent lower in 2001.

Because convenience use had a significant effect on the level and growth of measured credit card debt, researchers should exercise caution when interpreting increases in this measure 
of debt, particularly over long periods. Specifically, some of the increase in debt may be associated with the growth of convenience use, which will likely be paid off by the consumer; therefore, this growth should not be construed as an increase in the financial fragility of the U.S. household sector. Growth of convenience use relative to new borrowing may also have important implications for the health of financial institutions that issue credit card debt because households may be less likely to default on convenience use than on new borrowing.

This paper addressed the effect of convenience use on measured credit card debt and concluded that this effect was notable. However, the other component of measured credit card debt - the amount borrowed by households - also grew rapidly relative to household income during the 1990s. Little research has examined the source of this increase. Further research on this topic, coupled with the analysis of convenience use presented here, would greatly enhance our understanding of household credit use. 


\section{Appendix: Estimating Convenience Use and Demand for New Borrowing from the Survey of Consumer Finances}

I used the 1992-2001 waves of the SCF to estimate the effect of convenience use on credit card charges. ${ }^{17}$ Each wave of the survey asked respondents roughly what charges they made to their general-purpose card accounts (Visa, MasterCard, Discover, or Optima) and their store card accounts, as reported on their last bills. Although the survey also asked for charges on cards used for gas, travel and entertainment, and other special purposes, I did not include these charges in the main analysis because the survey did not record other characteristics of special-purpose cards, such as interest rates and information on whether respondents regularly paid off the cards.

According to the model developed above, credit card charges depend on the demand for new borrowing and the demand for convenience. I measured convenience demand by using a dummy variable for whether a household always or almost always paid off the total balance owed on its general-purpose and store cards.

The demand for new borrowing depends on the household's income, wealth, demographic characteristics, rate of time preference, and the interest rate. I used the implicit price deflator for personal consumption expenditures to inflate all financial variables to 2001 dollars. ${ }^{18}$ Household income equals total pretax income from all sources in the previous year. To construct a proxy for unanticipated shocks to income, I included a variable that equals 1 if the household reported that its previous year's income was unusually high, -1 if the household reported that such income was unusually low, and 0 otherwise. I used the number of years of education to control for expected future income. Household heads with temporarily low income-such as those who are unemployed or those who are on sick leave or maternity leave and expect to return to work--use debt to maintain their consumption, and so I also included a dummy variable for households whose head is temporarily out of work.

I calculated household wealth as follows:

Household wealth $=T A-C C D+F N F+R$, where

$T A=$ transactions accounts, including checking, savings, and money

\footnotetext{
${ }^{17}$ For a detailed discussion of the SCF and to gain access to the survey data, see www.federalreserve.gov/pubs/oss/oss2/scfindex.html.

${ }^{18}$ See Bureau of Economic Analysis, Survey of Current Business, table 7.1.
} 
market accounts and call accounts at brokerages

$C C D=$ outstanding credit card debt

$F N F=$ financial and nonfinancial assets, such as stocks, bonds, and

housing, net of debt secured by these assets

$R=$ retirement assets, such as IRAs and Keoghs, net of debt secured by these assets.

I included in the demand function the wealth measure squared because many consumption functions approximated in the literature (Zeldes, 1989; Deaton, 1991; Carroll and Kimball, 1996; Carroll, 1997; Parker, 1999) are concave in current liquid wealth.

I included several demographic variables that plausibly affect consumption. To control for a household's stage in the life cycle, I included the household head's age as well as the number of children under age eighteen. I also added dummy variables for married and male household heads.

The household's rate of time preference is difficult to measure. I assumed that a household that looks one year or less into the future when making financial decisions heavily discounts the future. For such a household, I included a dummy variable that equals 1 for a high discount rate. The credit card interest rate recorded by the SCF is the rate on the account in which the household has the highest balance. This rate may be lower than the average rate on all of a household's cards if the household rationally borrows at the lowest interest rate. Because this rate was recorded only in the 1995, 1998, and 2001 waves of the survey, I omitted it from the baseline regression.

To capture other time-varying components of the demand for new borrowing, such as the business cycle, I included time dummies for the 1995, 1998, and 2001 waves. Finally, to estimate the effect of changes in convenience use over time, I included these time dummies interacted with a dummy for whether the household is a convenience user. 


\section{References}

Bacchetta, P., and S. Gerlach (1997). "Consumption and Credit Constraints: International Evidence." Journal of Monetary Economics, vol. 40 (October), pp. 207-38.

Board of Governors of the Federal Reserve System, Quarterly Report of Credit Card Interest Rates, Form FR 2835a, www.federalreserve.gov/boarddocs/reportforms/default.cfm.

Board of Governors of the Federal Reserve System, Statistical Release G.19, "Consumer Credit," www.federalreserve.gov/releases/g19/.

Carroll, C. (1997). "Buffer-stock Saving and the Life-cycle/Permanent Income Hypothesis," The Quarterly Journal of Economics, vol. 112 (February), pp. 1-55.

Carroll, C., and W. Dunn (1997). "Unemployment Expectations, Jumping (S,s) Triggers, and Household Balance Sheets.” In NBER Macroeconomics Annual 1997. Cambridge, Mass.: MIT Press, 165-217.

Carroll, C. and M. Kimball (1996). "On the Concavity of the Consumption Function." Econometrica, vol. 64 (July), pp. 981-92.

Chung, C., and A. Goldberger (1984). "Proportional Projections in Limited Dependent Variable Models." Econometrica, vol. 52 (March), pp. 531-34.

Deaton, A. (1992). Understanding Consumption. New York: Oxford University Press.

Deaton, A. (1991). "Saving and Liquidity Constraints." Econometrica, vol. 59 (September), pp. 1221-48.

Duca, J., and W. Whitesell (1995). "Credit Cards and Money Demand: A Cross-sectional Study.” Journal of Money, Credit, and Banking, vol. 27 (May), pp. 604-23.

Durkin, T., and Z. Jonasson (2002). "An Empirical Evaluation of the Content and Cycle of Financial Reporting: The Case of Consumer Credit." Working Paper 64. Washington: Credit Research Center, McDonough School of Business, Georgetown University, April.

Evans D. and R. Schmalensee (1999), Paying with Plastic: The Digital Revolution in Buying and Borrowing. Cambridge, MA: MIT Press).

Goldberger, A. (1981). "Linear Regression after Selection," Journal of Econometrics, vol. 15 (April), pp. 357-66.

Greene, W. (1981). "On the Asymptotic Bias of the Ordinary Least Squares Estimator of the Tobit Model.” Econometrica, vol. 49 (March), pp. 505-13. 
Gross, D., and N. Souleles (2002). "Do Liquidity Constraints and Interest Rates Matter for Consumer Behavior? Evidence from Credit Card Data." Quarterly Journal of Economics, vol. 117 (February), pp. 149-85.

HSN Consultants, The Nilson Report. Oxnard, CA.

Klee, E. (2004). "Retail Payments 1995-2001: Findings from Aggregate Data and the Survey of Consumer Finances." Manuscript. Board of Governors of the Federal Reserve System, May.

Ludvigson, S. (1999). "Consumption and Credit: A Model of Time-Varying Liquidity Constraints." Review of Economics and Statistics, vol. 81 (August), pp. 434-47.

Maki, D. (2000). "The Growth of Consumer Credit and the Household Debt Service Burden." In Thomas A. Durkin and Michael E. Staten, eds., The Impact of Public Policy on Consumer Credit. Boston: Kluwer Academic Publishers.

Mandell, Lewis (1972). Credit Card Use in the United States. Ann Arbor, Mich.: Institute for Social Research.

Parker, J. (1999). "The Reaction of Household Consumption to Predictable Changes in Social Security Taxes." American Economic Review, vol. 89 (September), pp. 959-73.

United States Department of Commerce Economics and Statistics Administration, News, February 23, 2004, www.census.gov/eos/www/ebusiness614.htm.

Visa U.S.A. Business Research and Reporting, "U.S. Merchant Acceptance Locations," www.usa.visa.com/personal/newsroom/acceptance.html.

White, K. (1976). "The Effect of Bank Credit Cards on the Household Transactions Demand for Money." Journal of Money, Credit, and Banking, vol. 8 (February), pp. 51-61.

Whitesell, W. (1992). "Deposit Banks and the Market for Payment Media." Journal of Money, Credit, and Banking, vol. 24 (November), pp. 483-98.

Wooldridge, J. (2002). Econometric Analysis of Cross Section and Panel Data. Cambridge, Mass.: MIT Press.

Zeldes, Stephen P. (1989). "Optimal Consumption with Stochastic Income: Deviations from Certainty Equivalence," The Quarterly Journal of Economics, vol. 104 (May) , pp. 275298. 
Zinman, J. (2004). "Why Use Debit Instead of Credit? Consumer Choice in a Trillion Dollar Market." Paper presented in Atlanta at the Economics of Payments Conference, sponsored by the Federal Reserve Bank of Atlanta and the Federal Reserve Bank of New York, March 31-April 1, 2004. 
1. Ratio of credit card transaction volume to outstanding credit, 1990-2002

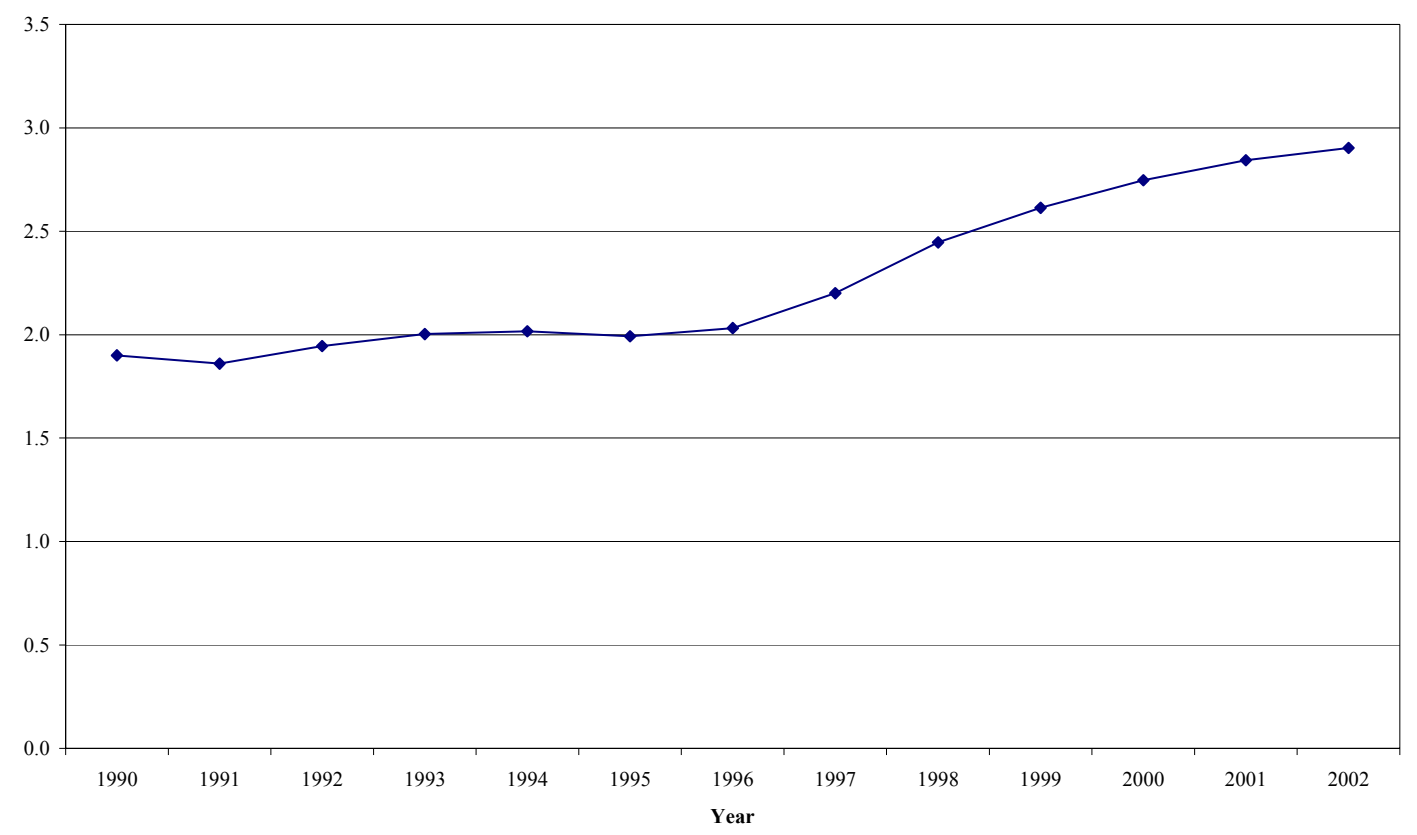

Source: The Nilson Report.

2. Median credit card charges, by household payment behavior, selected years

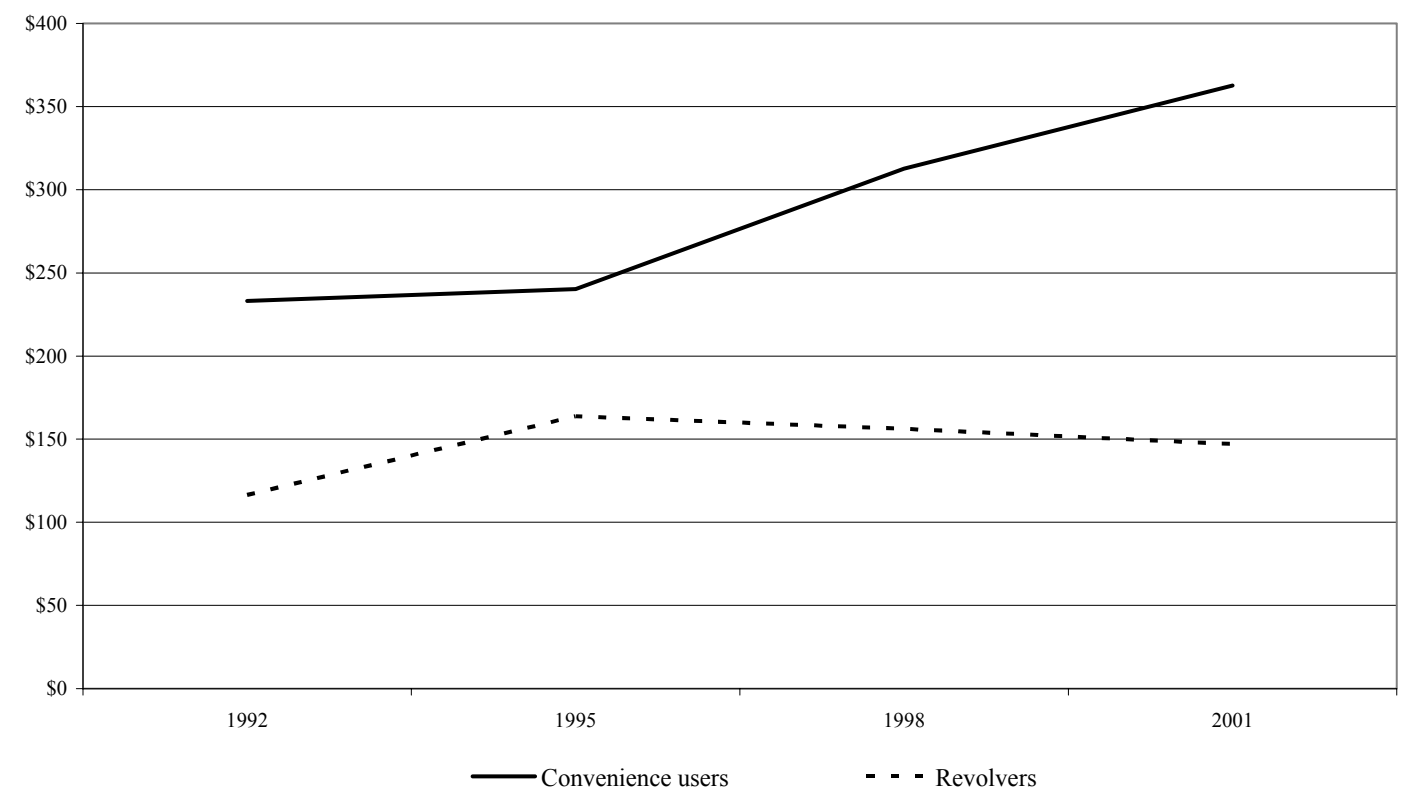

Source: Survey of Consumer Finances 
3. Composition of estimated charges of convenience users, selected years

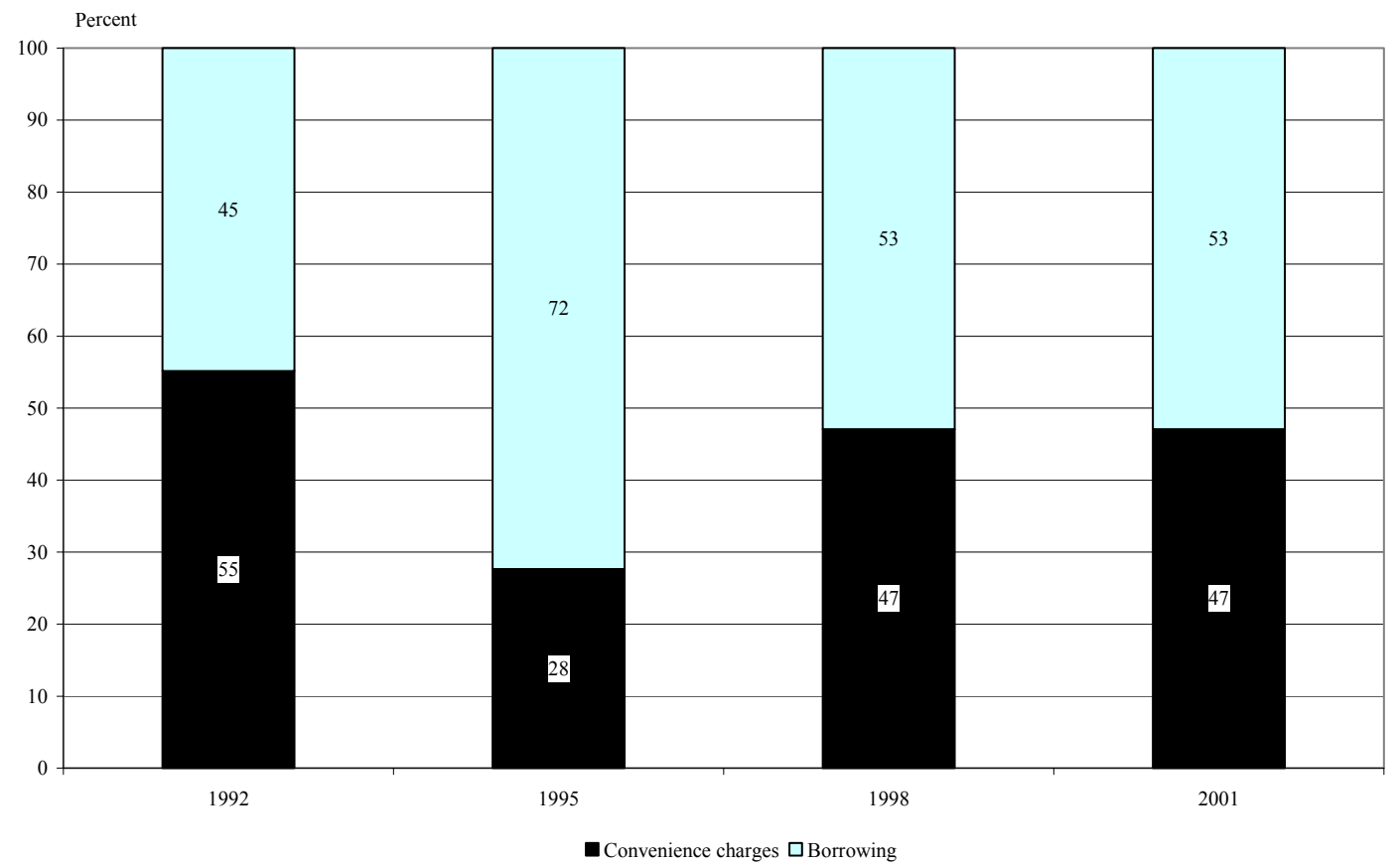

Source: Survey of Consumer Finances and author's calculations.

4. Convenience use for alternative specifications

Percent of measured credit

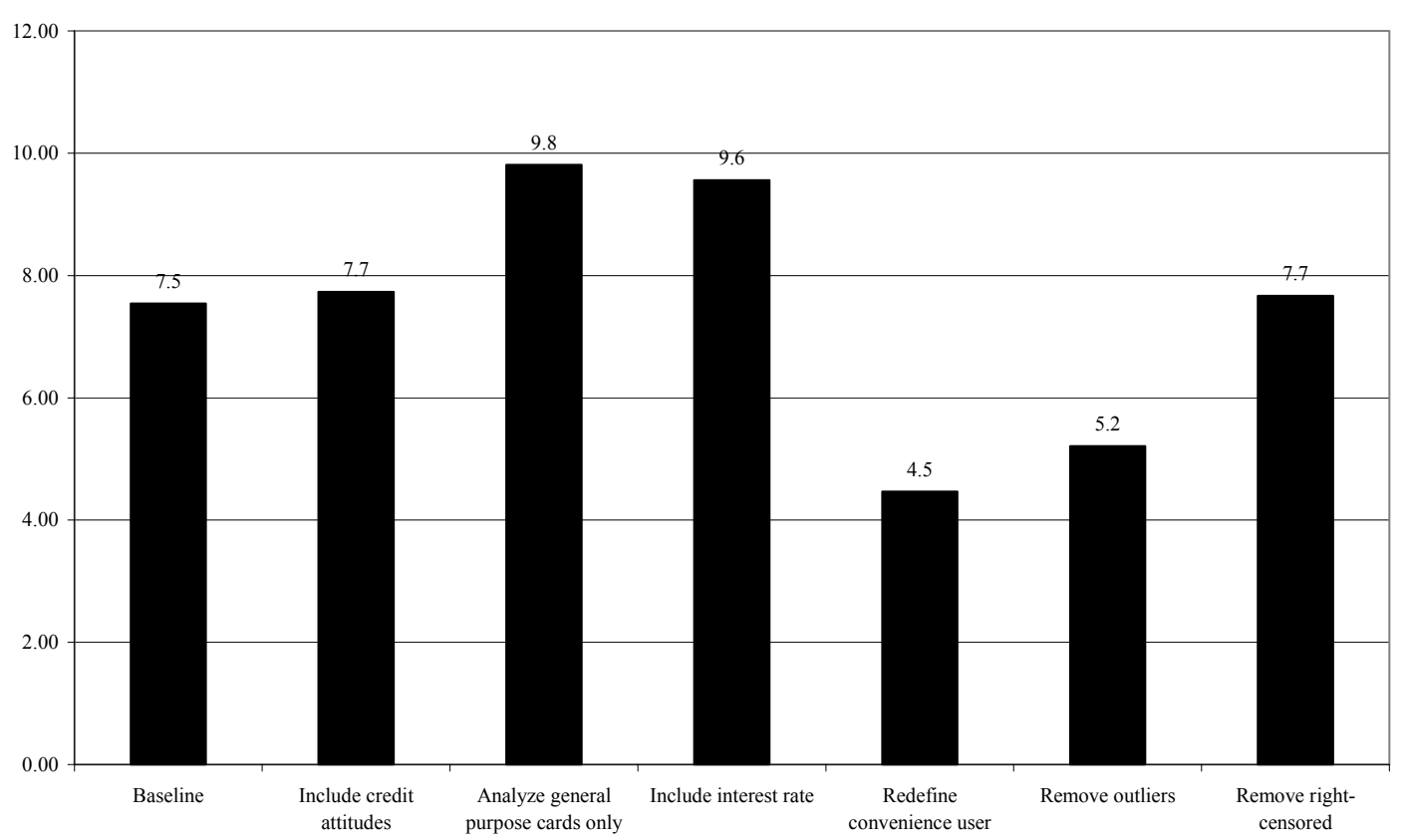

Source: Survey of Consumer Finances and author's calculations 
5. Increase in components of measured credit card debt, selected years

Index: $1992=100$

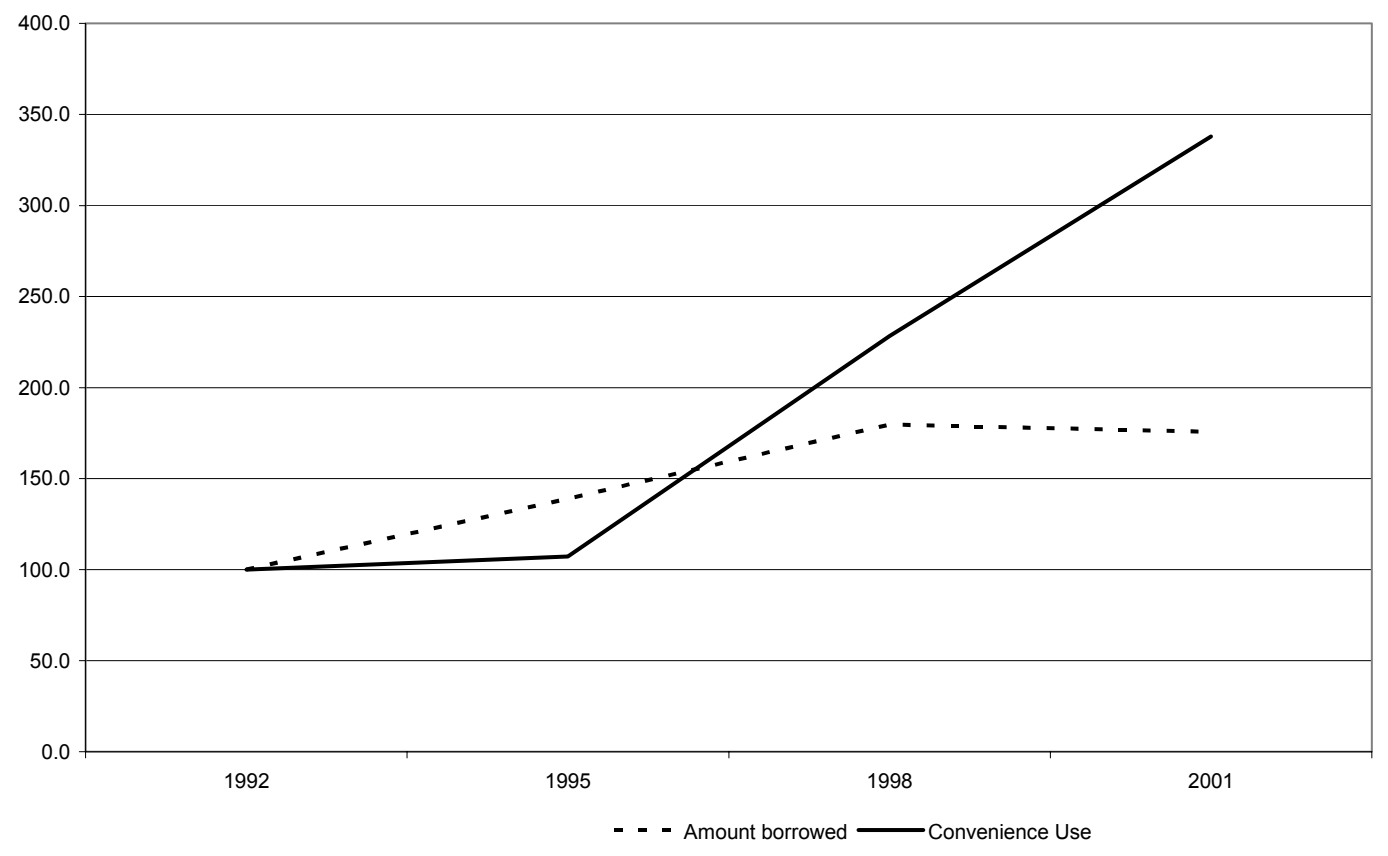

Source: Survey of Consumer Finances and author's calculations.

6. Convenience use and the increase in measured credit card debt, selected years

Billions of real 2000 dollars

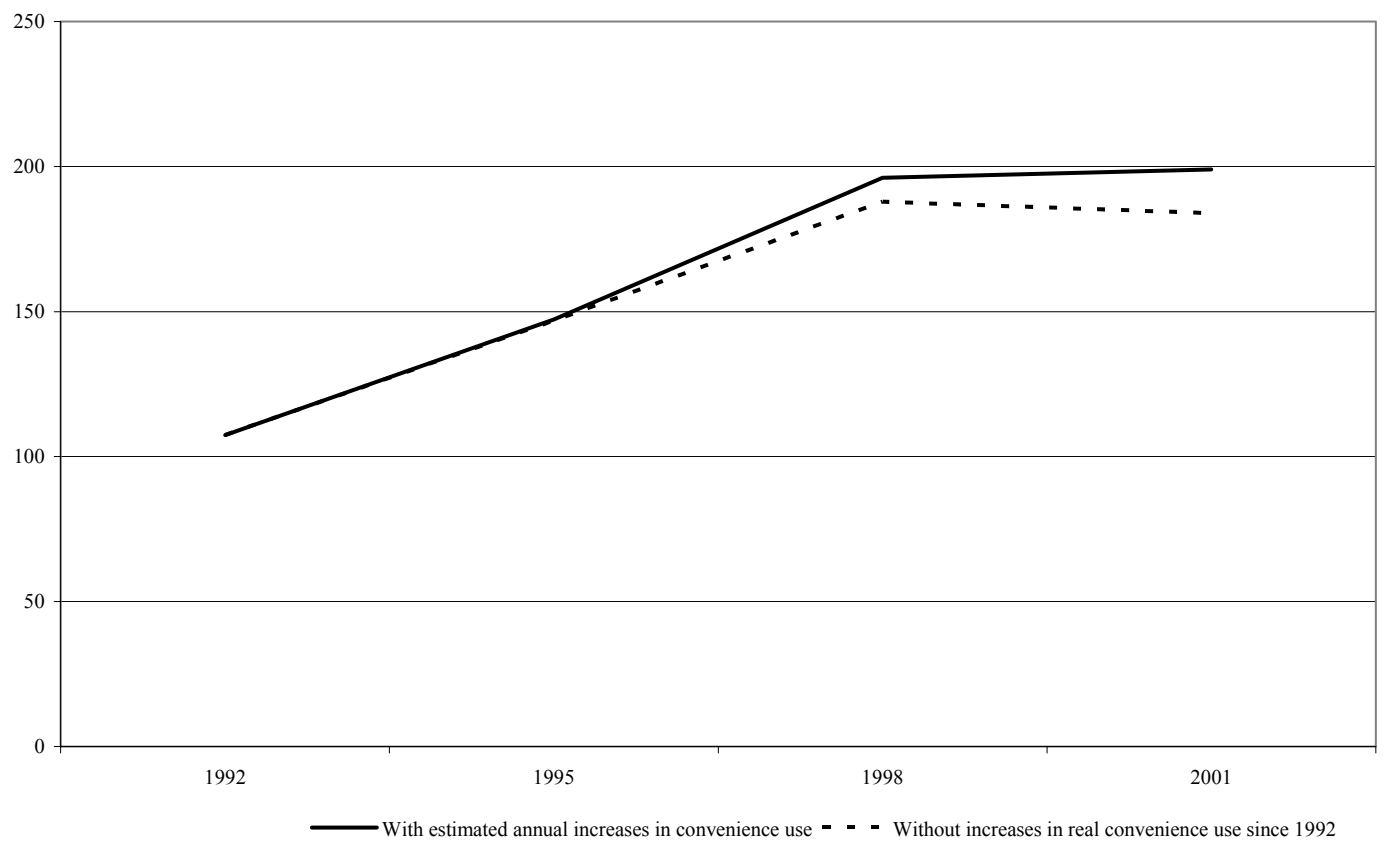

Source: Survey of Consumer Finances and author's calculations. 
1. Credit card payment behavior of U.S. households, selected years

Percent

Pay total balance on account each month

1992

1995

1998

2001

Always or almost always

$\begin{array}{llll}51.3 & 51.5 & 53.2 & 54.9 \\ 19.6 & 19.9 & 19.3 & 19.3 \\ 29.1 & 28.6 & 27.5 & 25.8\end{array}$

Hardly ever

Note: Survey respondents were asked, "Thinking only about Visa, Mastercard, Discover, Optima, and store cards, do you always (or almost always), sometimes or hardly ever pay off the total balance owed on the account each month?"

Source: Survey of Consumer Finances.

2. Calculating the share of convenience use, selected years

Billions of real 2000 dollars except where noted

\begin{tabular}{lrrrr} 
Measured card debt & 1992 & 1995 & 1998 & 2001 \\
\hline \hline & 119.9 & 168.0 & 214.3 & 223.0 \\
Total & 101.1 & 140.5 & 181.6 & 177.6 \\
Amount borrowed & 91.6 & 126.2 & 163.2 & 157.5 \\
$\quad$ By revolvers & 9.4 & 14.3 & 18.4 & 20.1 \\
By convenience users & 18.8 & 27.5 & 32.7 & 45.4 \\
Credit card charges of convenience users & 15.7 & 16.4 & 15.3 & 20.4 \\
As a percent of total measured card debt & & & &
\end{tabular}

Source: Survey of Consumer Finances 
3. Effect of household characteristics on new credit card charges, selected years.

\begin{tabular}{|c|c|c|c|c|}
\hline \multirow[b]{2}{*}{ Household Characteristic } & \multicolumn{4}{|c|}{ Standard } \\
\hline & \multicolumn{2}{|l|}{ Coefficient } & error & t-stat \\
\hline Convenience user in 1992 & 181.80 & $*$ & 54.93 & 3.31 \\
\hline in 1995 & 82.19 & & 75.28 & 1.09 \\
\hline in 1998 & 186.14 & $*$ & 75.77 & 2.46 \\
\hline in 2001 & 302.40 & $*$ & 74.94 & 4.04 \\
\hline \multicolumn{5}{|l|}{ Financial } \\
\hline Income & 13.77 & $*$ & 1.07 & 12.89 \\
\hline Income squared & $-1.10 \mathrm{E}-03$ & & 0.00 & -9.22 \\
\hline Wealth & 0.15 & $*$ & 0.01 & 16.59 \\
\hline Wealth squared & $-1.77 \mathrm{E}-07$ & & 0.00 & -8.94 \\
\hline Unusually high income & 20.71 & & 26.50 & 0.78 \\
\hline Unemployed head of household & 120.38 & & 80.73 & 1.49 \\
\hline \multicolumn{5}{|l|}{ Demographics } \\
\hline Years of education & 89.20 & $*$ & 5.28 & 16.89 \\
\hline Age of household head & 0.82 & & 0.94 & 0.87 \\
\hline Gender of household head & 107.55 & $*$ & 43.19 & 2.49 \\
\hline Number of children & 29.45 & $*$ & 13.81 & 2.13 \\
\hline Married & 179.83 & $*$ & 38.18 & 4.71 \\
\hline Rate of time preference & -102.82 & & 29.77 & -3.45 \\
\hline \multicolumn{5}{|l|}{ Time dummy for household } \\
\hline 1995 sample & 184.40 & $*$ & 54.39 & 3.39 \\
\hline 1998 sample & 108.58 & $*$ & 55.33 & 1.96 \\
\hline 2001 sample & 159.51 & $*$ & 55.19 & 2.89 \\
\hline Constant & -1429.88 & & 105.99 & -13.49 \\
\hline
\end{tabular}

* Significantly different from zero at the 5 percent confidence level 
4. Calculating the share of convenience with the baseline, Tobit estimates, selected years Billions of real 2000 dollars except where noted

\begin{tabular}{lrrrr} 
Measured card debt & 1992 & 1995 & 1998 & 2001 \\
\hline \hline & & & & \\
Total & 107.4 & 147.3 & 196.1 & 199.0 \\
Amount borrowed & 101.1 & 140.5 & 181.6 & 177.6 \\
$\quad$ by revolvers & 91.6 & 126.2 & 163.2 & 157.5 \\
by convenience users & 9.4 & 14.3 & 18.4 & 20.1 \\
Convenience use & 6.3 & 6.8 & 14.5 & 21.4 \\
As a percent of total measured card debt & 5.9 & 4.6 & 7.4 & 10.8
\end{tabular}

Source: Survey of Consumer Finances and author's calculations. 